DOI: doi.org/10.18372/38239

UDC: 536.6:621.43.055

\title{
2.4 MEANS OF QUALITY CONTROL OF BIOFUELS, THEIR PRODUCTION AND COMBUSTION
}

\author{
Artur Zaporozhets, Serhii Ivanov, Roman Serhiienko
}

In the structure of Ukraine's exports, products of the agricultural sector and the food industry occupy the highest position. This draws attention to Ukraine because of the potential for the development of bioenergy through the processing of biomass and agricultural waste into fuel briquettes and pellets. Moreover, according to the «New Energy Strategy of Ukraine» [1], by 2020 the share of renewable energy sources should be at least $11 \%$, a substantial part of which will be solid fuel of plant origin. For achieving these indicators, an integrated approach to improve the efficiency of pellet production is needed, as well as to control not only the quality of the finished product, but also the parameters of such fuel burning. This requires methodological and hardware control of informative parameters at each stage of the existence of this plant fuel: from the preparation to the combustion of raw materials.

Production control. The technology of manufacturing of fuel pellets from vegetable raw materials involves three main stages: preliminary grinding, drying, and the formation of the finished product by pressing.

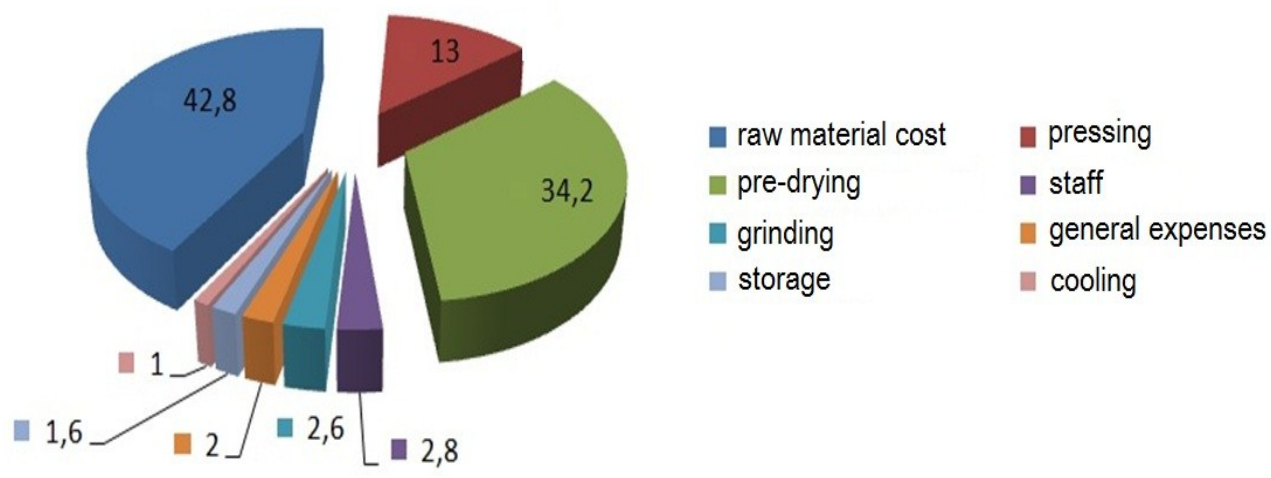

Fig. 1. The diagram of the cost of production of vegetable pellets

In the cost structure of production of fuel briquettes or pellets from woodworking or food industry waste, the cost of drying raw materials can reach $45 \%$, therefore one of the promising ways to reduce the cost of such fuel is the efficient using of energy for the drying process.

The criterion for optimizing the drying process of any material is the Rebinder criterion [2], to determine which it is necessary to know the heat capacity of the material and the heat of evaporation of moisture from it for a specific temperature and humidity of the studied raw materials. Plant materials are heterogeneous in structure, biological material, drying of which is accompanied by secondary exothermic and endothermic processes, such as crystallization, structural changes in proteins, changes in the concentration of the components of organic substances during evaporation, etc. It is extremely difficult to take into account the influence of such factors on the amount of evaporation heat using analytical methods, therefore it is preferable to use data from direct experimental measurements. For an experimental study of the specific heat 
of evaporation and the heat capacity of inhomogeneous wet materials, a measuring system [3] was developed and created, which allows to implement two different research methods using a single device (Fig. 2).

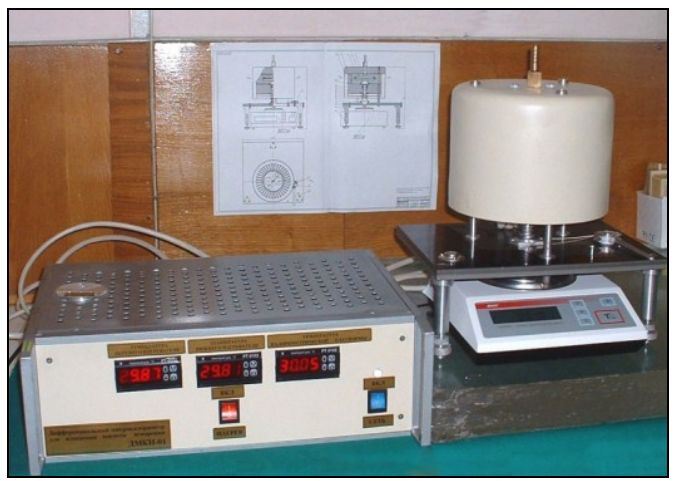

(a)

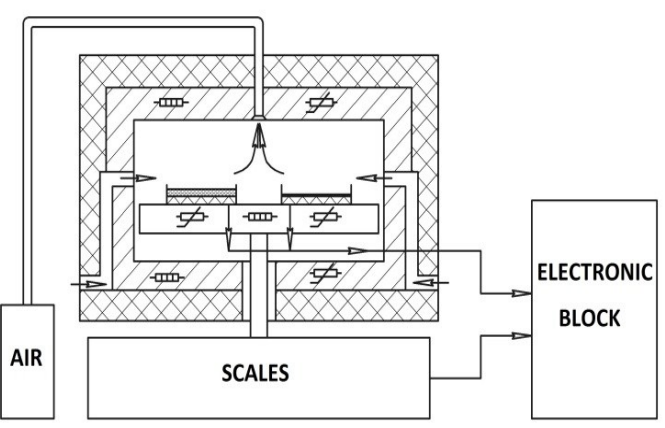

(b)

Fig. 2. Appearance of the device $(a)$ and the structure of the thermal block $(b)$

The device is constructed as a block-modular system, each of the individual blocks of which implements separate functional tasks.

The thermal unit is designed to accommodate the sample and the implementation of the temperature conditions of the experiment. The sample is placed in one of two differentially connected calorimetric cells, which are mounted into a common high-heat conductive base and form a calorimetric platform.

Several calorimetric platforms with cells of different configurations have been designed for the device (Fig. 3).
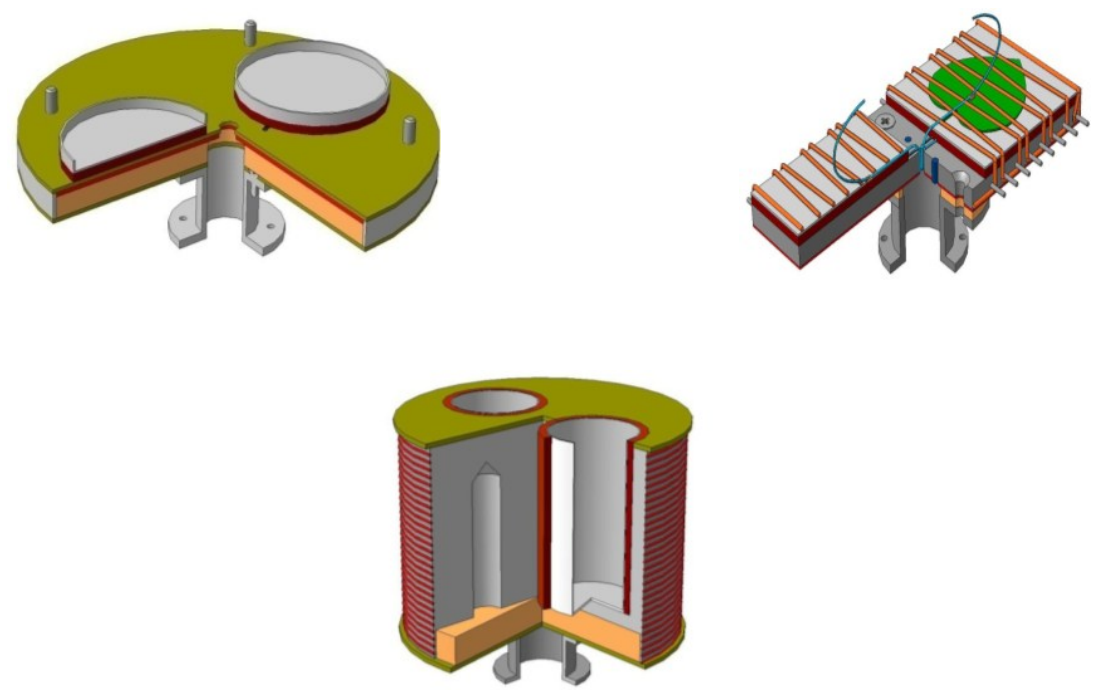

Fig. 3. Different types of calorimetric platforms

Platforms are designed as replaceable elements of the thermal unit, which allows to significantly expand the range of materials under study. Such solution makes it possible to obtain 
correct data on the heat capacity and heat of evaporation in the study of liquors, viscous samples, capillary-porous bodies, thin-sheet materials with a tendency to deform during drying, bulk materials of varying degrees of dispersion, etc. In the upper and lower parts of the working chamber, as well as directly in the calorimetric platform, electric heaters are mounted with an independent temperature control system to provide an isothermal environment in the working chamber of the device. The calorimetric platform is connected to an analytical balance, which ensures registration of the mass loss by the sample during drying. The air with the moisture, which was removed from the sample, are evacuated from the working chamber convectively through flexible tubes by a compressor.

The control unit is used for setting and maintaining the temperature conditions of the experiment. In addition, it is necessary to convert the data from the thermal block on the parameters of the sample under investigation into digital form for its further processing by software.

Determination of heat of evaporation. To determine the specific heat of evaporation, the device provides for the using of the method of synchronous thermal analysis and the simultaneous application of the methods of differential calorimetry and thermogravimetric analysis. The method is based on the assumption that under isothermal conditions, the heat that is supplied to a thin layer of inert moist material is consumed to evaporate the liquid from it. The system provides for the reproduction of the isothermal environment in which the sample under study is placed. Heat is supplied to the sample by conduction, and its quantity is recorded by heat flow sensors that are connected in a differential measurement circuit. At the same time, the amount of liquid that has evaporated from the surface of the sample in the same time is determined.

The heat of evaporation $r$ for an arbitrary point in time in a generalized form is defined as the ratio of these quantities:

$$
r(T)=\frac{\left(Q_{1}-Q_{2}\right)}{d m / d \tau}
$$

where $r(T)$ - specific heat of evaporation at the temperature $T ; Q_{1}$ - eat flux recorded by the cell sensor with the sample; $Q_{2}$ - heat flow recorded by the sensor of the empty reference cell; $d m / d \tau$ - sample mass loss rate.

Calibration device for the heat of evaporation is performed by examining the unknown quantities in pure well-characterized model substances. Distilled water and propanol were used as such exemplary substances. The results of the verification showed that the error in determining the heat of evaporation using the presented instrument does not exceed $1.5 \%$.

The determination of heat capacity in the presented device is carried out using a standardized method of step-by-step scanning. According to this method, the temperature range in which the research is planned to be carried out is divided into separate intervals (steps) of successive increase in temperature in the working chamber. The duration of each interval should be sufficient for the formation in the working chamber of a stationary temperature regime. A sample of a known mass is placed in the working cell of the device, after which the cells are hermetically sealed with a vapor barrier to prevent the sample from changing its mass throughout the experiment. Heat flow sensors measure the amount of heat that was spent on heating a sample in a sealed cell with an increase in temperature in the working chamber for a given interval, as shown in Fig. 4.

The specific heat $\tilde{n}$ in the generalized form for one interval is determined by the formula:

$$
c=1 / m \cdot\left[\int_{\tau_{1}}^{\tau_{2}}\left(Q_{1}-Q_{2}\right) d \tau /\left(T_{2}-T_{1}\right)\right]
$$


where $c$ - specific heat of the sample; $T_{2}-T_{1}$ - the difference between the final and initial temperature values within the same interval.
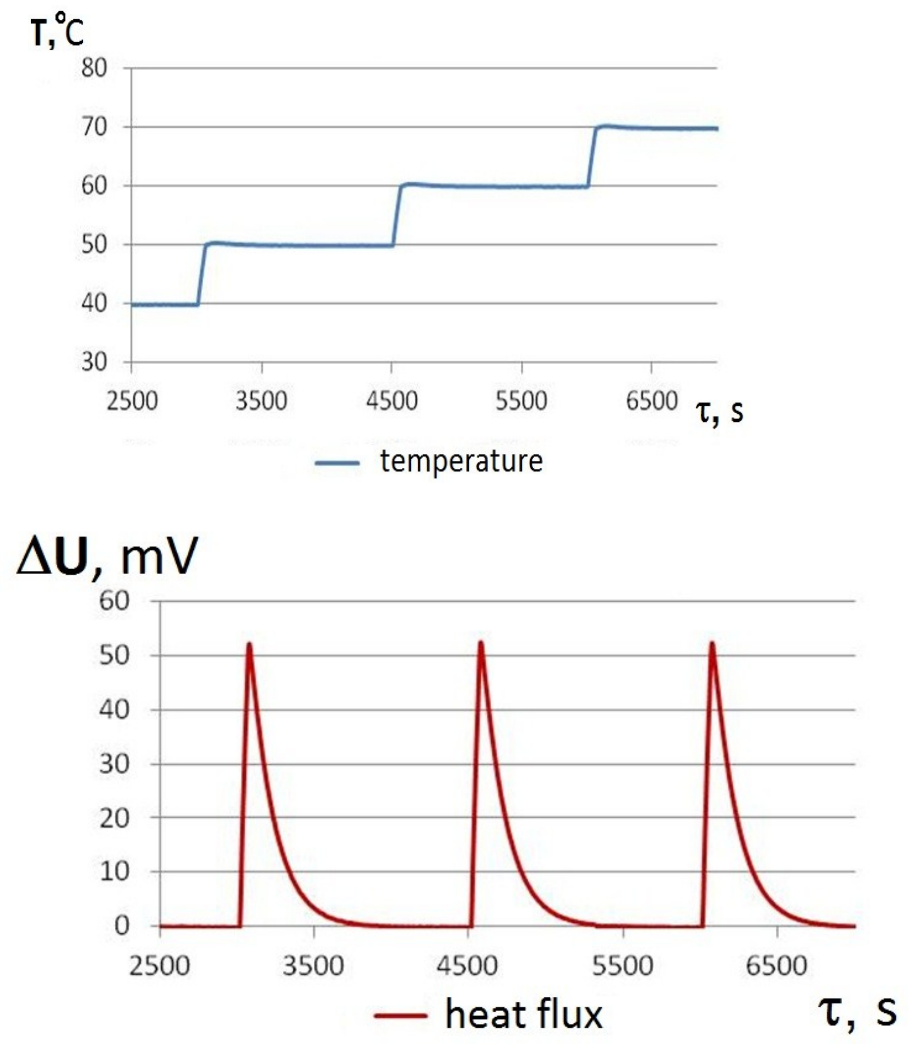

Fig. 4. Temperature change ( $a$ ) and recorded heat flux $(b)$ during using the step-by-step scanning method

The instrument is calibrated for heat capacity by studying the heat capacity of samples of pure inert materials with previously known well-studied thermophysical characteristics. According to the recommendations of the standard [4], a sample of leucosapphire with a purity of at least $99.99 \%$ is used as such a reference material.

The results of verification showed that the study of heat capacity by the method of step-bystep scanning using the presented system does not exceed $2.5 \%$.

The system was used for studying a wide range of wet materials, including complex integrated studies of the thermophysical and thermodynamic parameters of the plant components of biofuels [5].

Quality control. Formed and ready-to-use biofuels (fuel pellets), depending on their characteristics and properties, are assigned a quality category according to one of the international standards, for example EN 14961-2. The most informative parameter is the calorific value of the fuel, which is traditionally used to determine the method of bomb calorimetry.

The method of bomb calorimetry is based on measuring the amount of heat that is released when a sample of the fuel under investigation is burned in an oxygen atmosphere. Since solid fuel of plant origin is heterogeneous in structure and characteristics, special requirements are placed on bomb calorimeters for studying such material, including the need to ensure high capacity to accommodate a sufficient amount of the material under study, the ability to measure relatively powerful heat fluxes and, at the same time, the ensure high accuracy of measurement. 
Improving the accuracy of measuring the heat of combustion is achieved by using a differential measurement scheme, which is not always convenient when studying heterogeneous types of fuel, because the calorimeter with two full-sized cells has a significant inertia, high mass and low speed. An alternative could be a quasidifferential bomb calorimeter on Fig. 5. The appearance of the structure of the core of such a calorimeter is shown on Fig. 6. As in the classical calorimeter to determine the heat of combustion, this device has two cells, in one of which (the bomb) the sample is located, and the second (auxiliary) remains empty and serves to reduce the environmental impact on the measurement result. Both cells have their own heat flow sensor which has a cylindrical shape and covers the entire side surface of the cell.

A feature that distinguishes a quasidifferential bomb calorimeter from the classical one is the presence of an auxiliary cell, the dimensions of which are much smaller than the main one. Comparing the signals of the working and auxiliary cells is achieved by selecting the thermophysical parameters of the auxiliary cell's bomb simulator and amplifying its signal using a separate correction unit. The signal gain is determined at the instrument calibration stage.

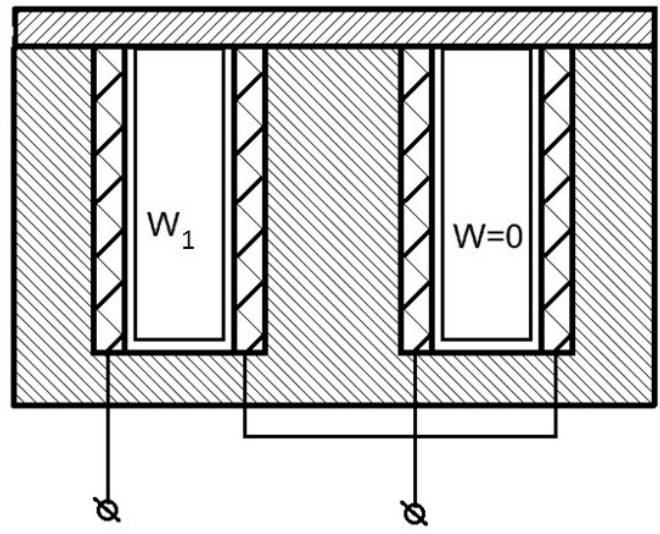

(a)

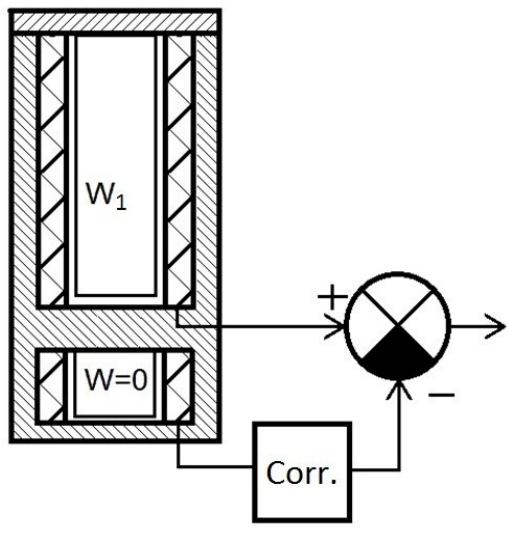

(b)

Fig. 5. Differences between differential $(a)$ and quasidifferential $(b)$ scheme of a bomb calorimeter

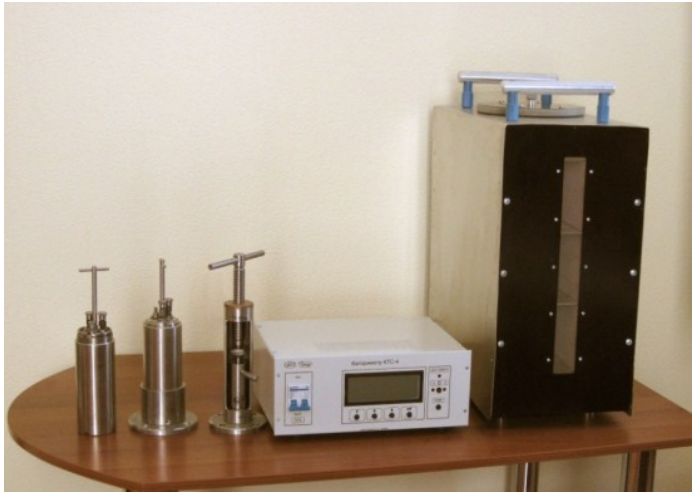

(a)

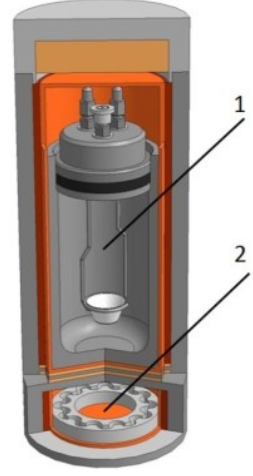

(b)

Fig. 6. The appearance of a quasidifferential bomb calorimeter $(a)$ and the design of the devices's core $(b): 1-$ fuel sample bomb; 2 - bomb simulator 
The principle of operation of the calorimeter is based on measuring the heat flux generated during the combustion of a fuel sample, and its integration, as a result of which it is determined the heat released during the fuel combustion.

Compared to other models of KTS calorimeters [6], a number of improvements have been added to the design of the KTS-4 device (Fig. 6), aimed at improving manufacturability, reducing preparation time and improving measurement accuracy. The measurement range of the calorimeter is from 10 to $40 \mathrm{~kJ}$, the measurement error is $\pm 0.1 \%$, the duration of the preparation process is no more than 90 minutes, the duration of the measurement process is 30 minutes. Technical characteristics of the KTS-4 bomb calorimeter are given in Table. 1.

Main technical characteristics of the KTS-4 bomb calorimeter

\begin{tabular}{|l|c|}
\hline \multicolumn{1}{|c|}{ Parameter } & Value \\
\hline Range of measured quantity of heat, $\mathrm{kJ}$ & $10-40$ \\
\hline The limits of permissible relative error, $\%$ & \pm 0.1 \\
\hline Total preparation time for measurements, min & $\leq 90$ \\
\hline Measurement time, min & 30 \\
\hline Power (220 V, 50 Hz), W & $\leq 850$ \\
\hline Indication of measurement results & digital \\
\hline Mass, kg & 50.0 \\
$-\quad$ thermal unit & 15.0 \\
$-\quad$ electronic unit & 2.5 \\
\hline
\end{tabular}

Table 1

The KTS-4 bomb calorimeter includes:

1) a thermal unit designed to place a sample of fuel in it, to ensure the required temperature mode of operation and to measure heat generation from a bomb when a sample of fuel is burned;

2) two calorimetric bombs BKU-2 intended for burning a sample of fuel in the oxygen atmosphere;

3) an electronic unit designed to regulate the thermal regime, measure and process signals from the primary transducers, generate an electrical pulse to burn a fuel sample, and transfer measurement information to a personal computer.

The thermal unit of the device (Fig. 7) has a cylindrical sensitive heat-metering shell 6 , in the internal space of which a calorimetric cell 5 is placed. Externally the heat-metering shell is surrounded by a thermal diffusion case 7 . A reaction vessel is placed in the cell - a calorimetric bomb containing a cup 3 with a lid 1 and a seal 2 . In the lower part of the case, a compensation cell 10 is coaxially mounted, surrounded by its own calorimetric shell 9 , which has the same diameter, design and density of thermoelements as the main shell. The compensation cell contains a simulated reaction vessel simulator with elements $12,13,14$ and has a specific heat capacity per unit area of the shell surface identical to the main one. There is an air gap 4 between the bomb glass and the working cell, and a gap 11 between the simulator and the compensation cell, and the case is protected by end insulation 8 .

Analytical solution of the non-stationary problem of heat conduction for the described model is almost impossible to obtain. At the same time, the presented model consists mainly of two types of structural elements, some of which have low thermal resistance and high heat capacity, while others have high resistance and low heat capacity. Such a system is quite well modeled as a system with lumped parameters.

Measurement of the amount of heat released during the combustion of a fuel sample is as follows. A fuel sample, prepared in accordance with the standards, is burned in a calorimetric 
bomb, which is installed in the thermal unit of the calorimeter and filled with oxygen with a pressure of 2.5...3 MPa. The surface temperature of the heat unit is stabilized with an electronic regulator.

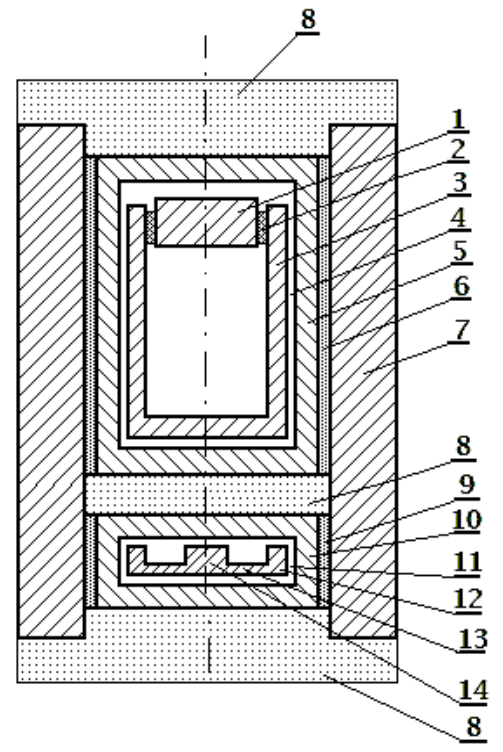

Fig. 7. Simplified model of the thermal unit of a quasi-differential calorimeter

The heat that is released during the combustion of a fuel sample is determined by integrating the heat flux, which is measured by a thermoelectric heat flux converter. Measurement and processing of information are carried out on the basis of a microprocessor device, and the result is displayed on a digital display of an electronic unit in the form of units of the amount of heat released during fuel combustion $(\mathrm{J} / \mathrm{kcal})$. The result is transmitted to a computer for further processing, specifically for the calculation of the highest and lowest calorific value, amendment, printing of the protocol. To eliminate the influence of temperature and air convection, the heat block of the calorimeter is placed in the climate chamber. To stabilize the supply voltage in the network using the mains voltage regulator.

During preparing the sample, the masses of the sample of the fuel material $M_{f u e l}$, copper inflammatory wire $M_{w l}$, plastic packaging $M_{p}$ and filler $M_{\text {fill }}$ are measured. During conducting a calorimetric experiment, the heat $Q_{\text {fuel }}$ generated by the sample burning is determined. After the experiment, the residual mass of the inflammatory wire $M_{w 2}$ is measured. The specific heat of fuel combustion in a bomb is calculated by the formula:

$$
q_{b}=\left[Q_{\text {fiel }}-q_{w} \cdot\left(M_{w 1}-M_{w 2}\right)-q_{p} \cdot M_{p}-q_{\text {fill }} \cdot M_{\text {fill }}\right] / M_{\text {fuel }},
$$

where $q_{b}$ - specific heat of fuel combustion in the bomber calorimeter, $\mathrm{J} / \mathrm{g} ; Q_{f u e l}-$ measured heat of fuel sample combustion, $\mathrm{J} ; q_{w}$ - specific heat of burning wire combustion $(2510 \mathrm{~J} / \mathrm{g}) ; q_{p}$ - specific heat of the polyethylene packaging $(46382 \mathrm{~J} / \mathrm{g}) ; q_{\text {fill }}$ - specific heat of filler combustion $(16700 \mathrm{~J} / \mathrm{g})$.

Fig. 8, for example, shows graphs of the change in heat flux $Q$ during the measurement time $t$ at the transition between stationary levels during the combustion of biomass samples in a bomb calorimeter.

In the course of experimental studies, two separate measurements of the heat of combustion of identical samples of wood pellets were carried out. It was established that the heat of 
combustion (after integrating the signal from the heat flow sensors) of the 1st sample was $\mathrm{Q}_{\mathrm{b} 1}=$ $11243 \mathrm{~J}$, the $2 \mathrm{nd}-\mathrm{Q}_{\mathrm{b} 2}=13273 \mathrm{~J}$ (in Fig. 8, the graphs of $\mathrm{E}_{1}$ and $\mathrm{E}_{2}$, respectively).

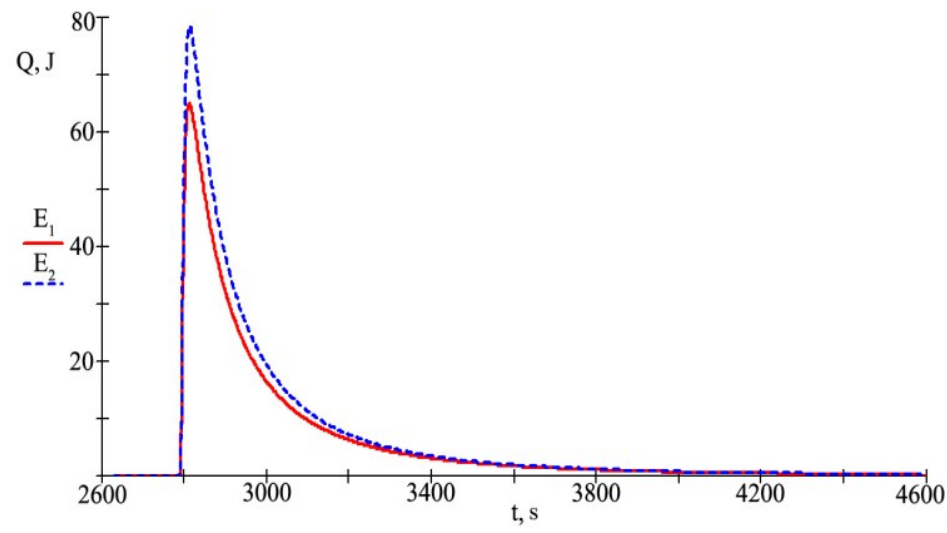

Fig. 8. Changes in heat flux during experimental studies on a bomb calorimeter

The work [7] confirmed the possibility of applying the method of reducing the time for measuring the specific heat of fuel combustion by interpolating the obtained data of the change in heat flux over time after reaching its peak value $(\approx 90 \mathrm{~s})$. To use this method, it is necessary to have empirical information about the nature of the non-stationary mode of combustion of a particular type of fuel in a bomb calorimeter.

The advantages of such calorimeter are: improved speed, weight and size parameters are reduced by $1.5 \ldots 2$ times (compared to a similar differential bomb calorimeter) while maintaining measurement accuracy in the range of $0.1 \%$. The effectiveness of the calorimeter was confirmed experimentally by studying biofuels of various nature [8].

Combustion control.To maintain high efficiency of the fuel system is not enough to use high-quality fuel, it is necessary to use effective modes of burning such fuel. Monitoring of the fuel combustion is reduced to monitoring the content of exhaust gases, while the objects of investigation are the fuel systems and air-fuel path [9]. The structural diagram of monitoring the fuel combustion is shown in Fig. 9.

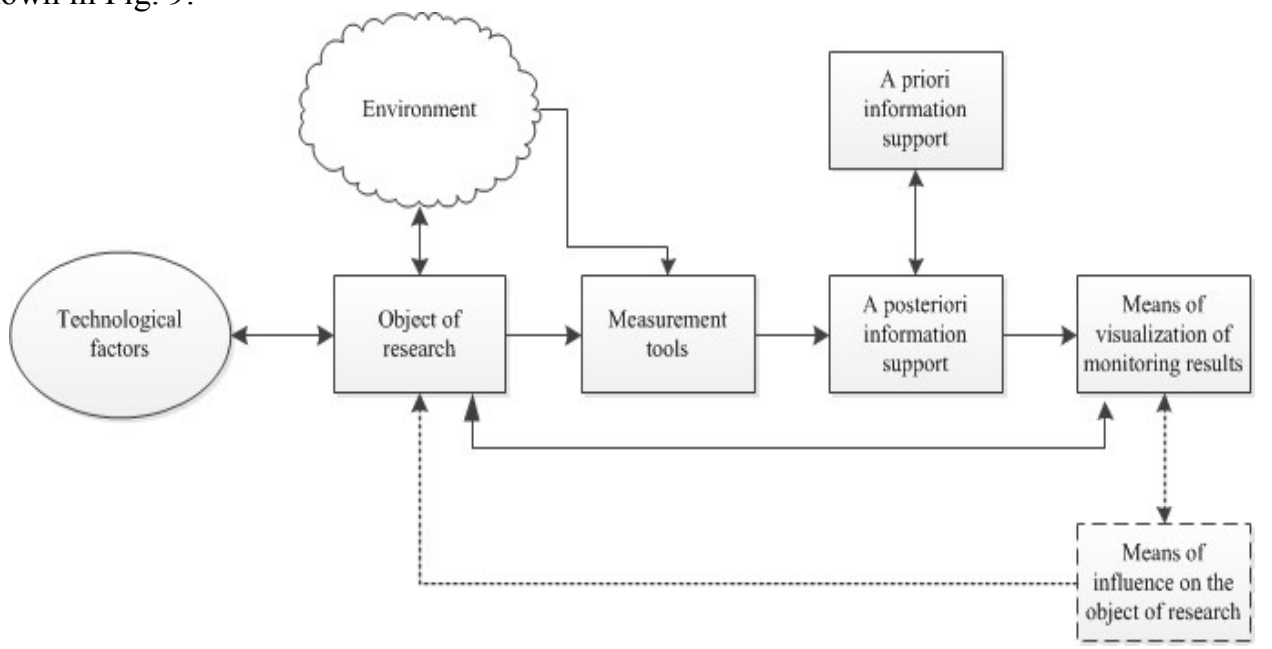

Fig. 9. Structural scheme of monitoring of combustion process 
The efficiency of the fuel system unit is determined on the basis of the efficiency of its components: burners, heating surfaces, heat exchangers (economizers, air heaters), draft machines and other devices. One of the most important components of the combustion process is the efficiency of fuel combustion, that is, the economy of the operation of the burners themselves and associated equipment (fans and smoke exhausters).

The main losses of heat during the natural gas combustion are heat losses with outgoing gases; thermal losses associated with chemical incompleteness of combustion; heat losses from heating surfaces. The heat losses with flue gases depends on: the temperature difference between the exhaust gases and the air supplied to the boiler furnace, and the residual oxygen content in the off-gas, that characterized the air excess ratio (AER, $\alpha$ ) or the air-fuel ratio. These losses are significant (for small and medium-sized fuel systems they can be from $10 \%$ to $26 \%$, for gas fuel system and boilers of power plants $-6-12 \%$ ) and mainly affect the efficiency of the fuel system.

In Fig. 10 shows heat losses with exhaust gases, calculated by the method of M.B. Ravich, for different values of the temperature of the outgoing gases.

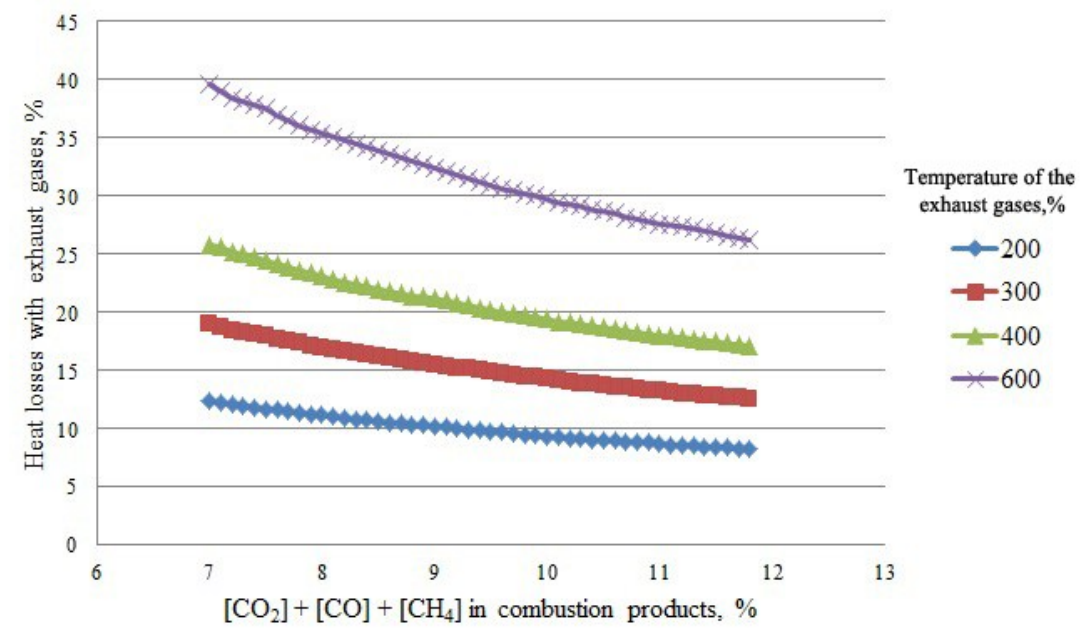

Fig. 10. Heat losses with exhaust gases in the fuel system with different composition of combustion products

According to the methodology based on the generalized characteristics of the fuel, during the combustion of natural and associated gases $q_{2}$ is determined by the formula (\%):

$$
q_{2}=0,01 \cdot z \cdot\left(t_{g}-t_{a}\right)
$$

where $z$ takes the tabulated value, $t_{g}$ - the temperature of the exhaust gases, $t_{a}-$ the ambient temperature. At the same time, increasing $t_{g}$ by $10{ }^{\circ} \mathrm{C}$ above the normal value for a given fuel system load cause increasing $q_{2}$ by at least $0.5 \%$, and increasing $\alpha$ by 0.1 cause increasing $q_{2}$ by about $1 \%$.

A number of requirements are put forward for the design and use of burners operating on liquid gaseous fuels, including compactness and ease of use, long service life and relatively low cost. But one of the most important requirements is the need to ensure complete and reliable combustion of fuel with a minimum excess of air, that is, burners must ensure the formation of a stoichiometric air-fuel mixture. Fig. 11 shows the factors affecting on the process of fuel combustion. 


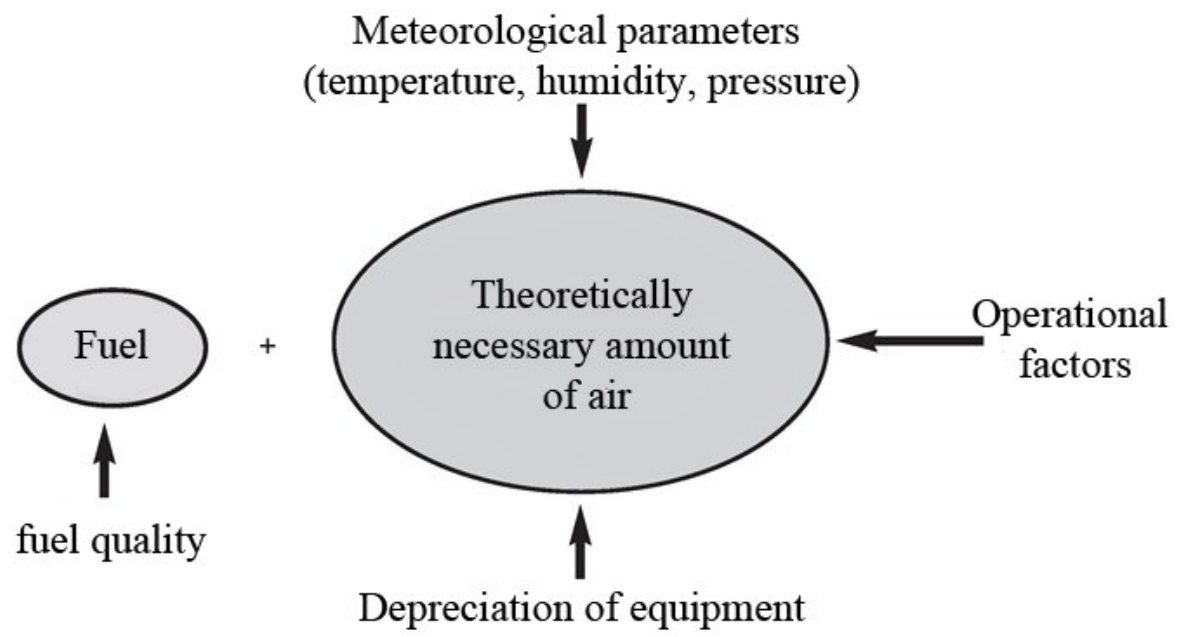

Fig. 11. Influencing factors for fuel combustion

A stoichiometric air-fuel mixture is a mixture containing exactly the same amount of oxidant as is necessary to completely oxidize the fuel. In practice, a lean air-fuel mixture is formed for fuel combustion, caused by a number of factors: insufficient fuel and oxidizer mixing, structural features of the fuel system, and the like.

Fig. 12 shows the theoretical dependences of the change in the mass ratio of the amount of air per unit of fuel for different AER values for some hydrocarbons [10].

Considering the problem of changes in combustion parameters over time, fluctuations in fuel quality and external factors of influence, it is effective not to use regime maps, but to regulate the parameters of their operation based on real-time computerized combustion control systems, by maintaining high efficiency of operation of fuel systems for solid fuel.

A fundamentally new approach to monitoring the fuel combustion is based on the using of a broadband oxygen sensor (Fig. 13)

A control block of the system of the fuel combustion in fuel systems of small and medium power based on an oxygen probe is shown in Fig. 14.

At present, oxygen probes are widespread in the automotive industry due to the constantly growing stringent regulations for the toxicity of off-gases. An essential advantage of such probes is the $\mathrm{CO}$ oxidation on the surface of the sensor containing $\mathrm{ZrO}_{2}$ in its composition. This makes it possible to obtain information on the actual oxygen concentration in the combustion products. The disadvantage of their application is the impossibility of detecting chemical underburning in the zone of $\alpha>1$, however, as experimental data showed, supporting the fuel system operation with an air excess ratio $\alpha \geq 1,1-1,15$ excludes the possibility of $C O$ formation at a level of more than 200 ppm.

The probe construct assumes the presence of two chambers (cells): measuring and pumping (Fig. 13b). Through the hole in the wall of the pump cell, the output gases enter the measuring chamber (diffusion gap) in the Nernst cell. This configuration is characterized by a constant maintenance of the stoichiometric air-fuel ratio in the diffusion chamber. The electronic circuit for the supply voltage modulating maintains in the measuring chamber the composition of the mixture corresponding to $\alpha=1$. For this purpose, the pump cell removes oxygen from the diffusion gap into the external medium with a lean mixture and an excess of oxygen in the flue gases, and, with the enriched mixture and insufficient oxygen, pumps the oxygen molecules from the surrounding medium into the diffusion gap. 

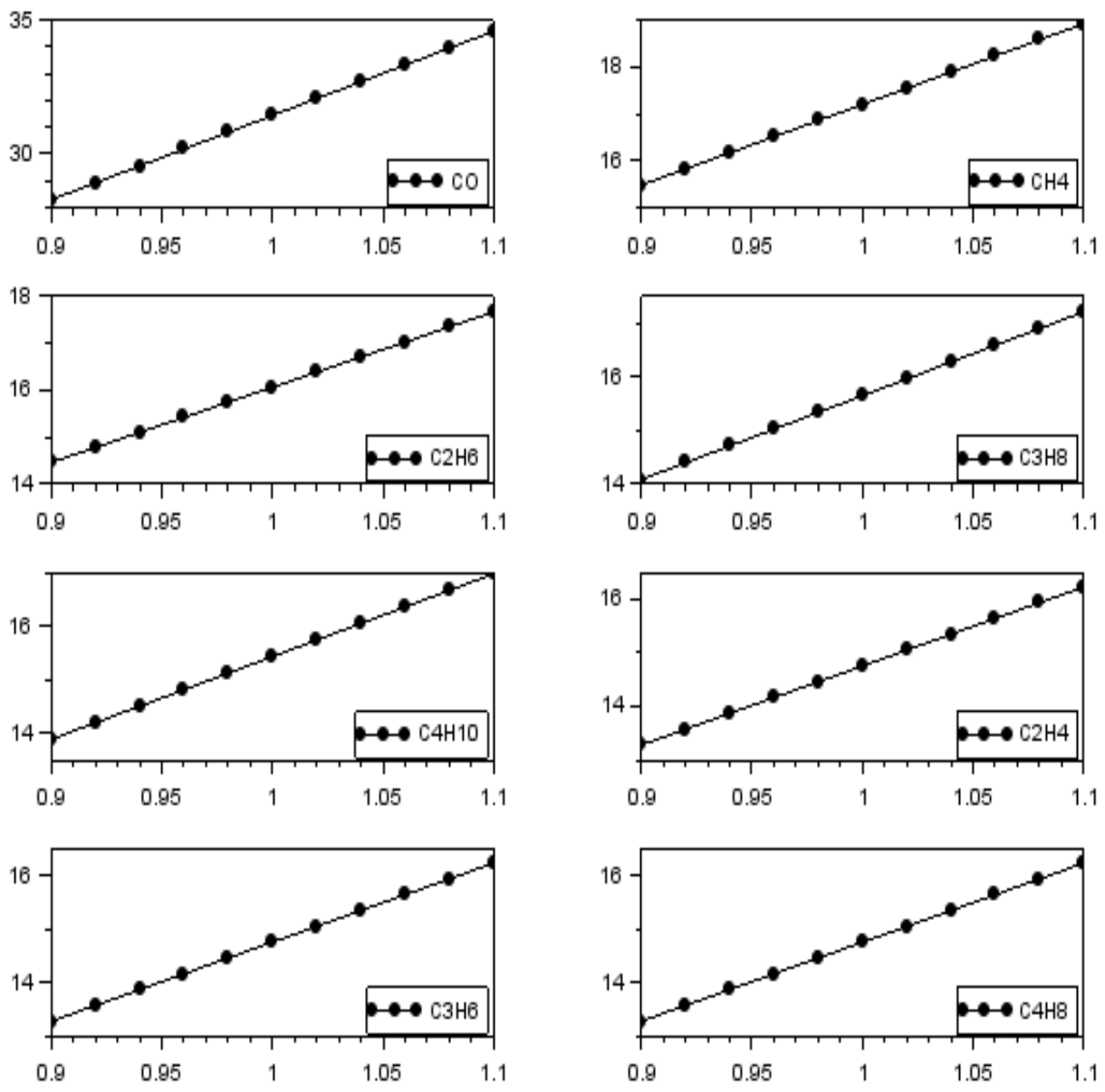

Fig. 12. The theoretical dependence of the change in air flow per unit of various types of fuel from the coefficient AER

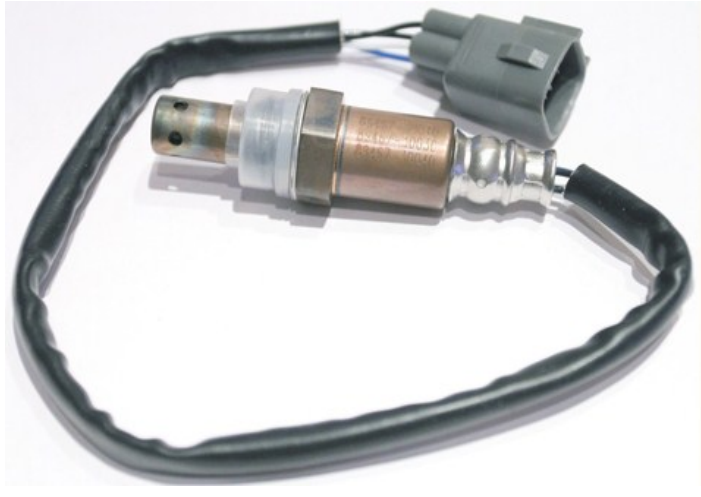

(a)

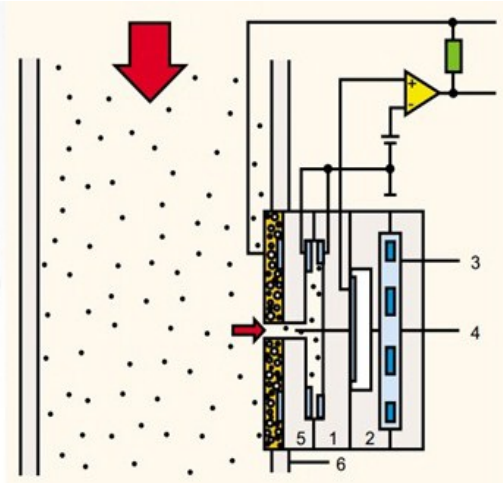

(b)

Fig. 13. Broadband oxygen probe: $a$-appearance; $b$ - structural scheme ( 1 - Nernst cell, 2 - reference cell, 3 - heater, 4 - diffusion slit, 5 - pumping cell, 6 - air and fuel tract) 
The main purpose of the control system is the speed regulation of the fan motor drive. This will encourage the optimum combustion regime in the boiler furnace, that is, provide the most favorable conditions for complete fuel combustion. The system supplies the required quantity of air to the furnace in terms of information received from its primary sensors (oxygen probe, temperature sensors and vacuum).

The task of maintaining the optimum combustion regime is ensured by selecting the necessary speed of motors rotation of the traction mechanisms with fully open guide devices in practically the entire range of the operating capacity of the $\mathrm{O}_{2}$-corrected combustion.

Technical characteristics of the monitoring system for the fuel combustion in fuel systems are given in Table. 2 .

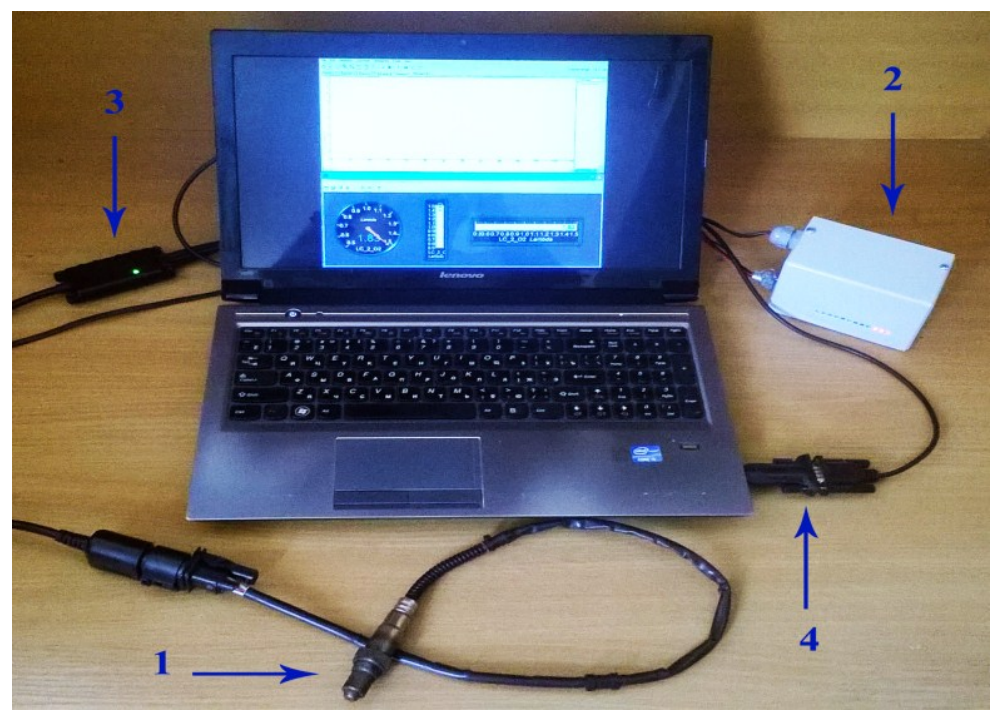

Fig. 14. A control block of the system of the fuel combustion in fuel systems: 1 - broadband oxygen probe, 2 - alpha indicator, 3 - controller, 4 - USB interface

Table 2

Technical characteristics of the monitoring system

\begin{tabular}{|l|c|}
\hline \multicolumn{1}{|c|}{ Parameter } & Value \\
\hline Output signal of the measuring probe, $\mathrm{V}$ & $+0.1 \ldots+5.0$ \\
\hline Recall (time delay of indication) for $50 \%$ step perturbation, $\mathrm{s}$ & $0.1 \ldots 0.3$ \\
\hline Initial preparation time for measurements, $\mathrm{s}$ & $\leq 30.0$ \\
\hline Measuring range of the parameter $\alpha$ & $0.5 \ldots 1.5$ \\
\hline Relative error, $\%$ & 3 \\
\hline Indication of measurement results & LED \\
\hline Cable length, $\mathrm{m}$ & $\leq 5$ \\
\hline Ambient temperature at relative humidity up to $80 \%:$ & \\
\hline display unit, ${ }^{\circ} \mathrm{C}$ & $5 \ldots 50$ \\
\hline boxes of the measuring probe, ${ }^{\circ} \mathrm{C}$ & $5 \ldots 70$ \\
\hline Conditions at the measurement point: & \\
\hline ambient temperature, ${ }^{\circ} \mathrm{C}$ & $50 \ldots 250$ \\
\hline flow rate, $\mathrm{m} / \mathrm{s}$ & $\leq 15$ \\
\hline pressure, $\mathrm{Pa}$ & $\leq++500$ \\
\hline
\end{tabular}




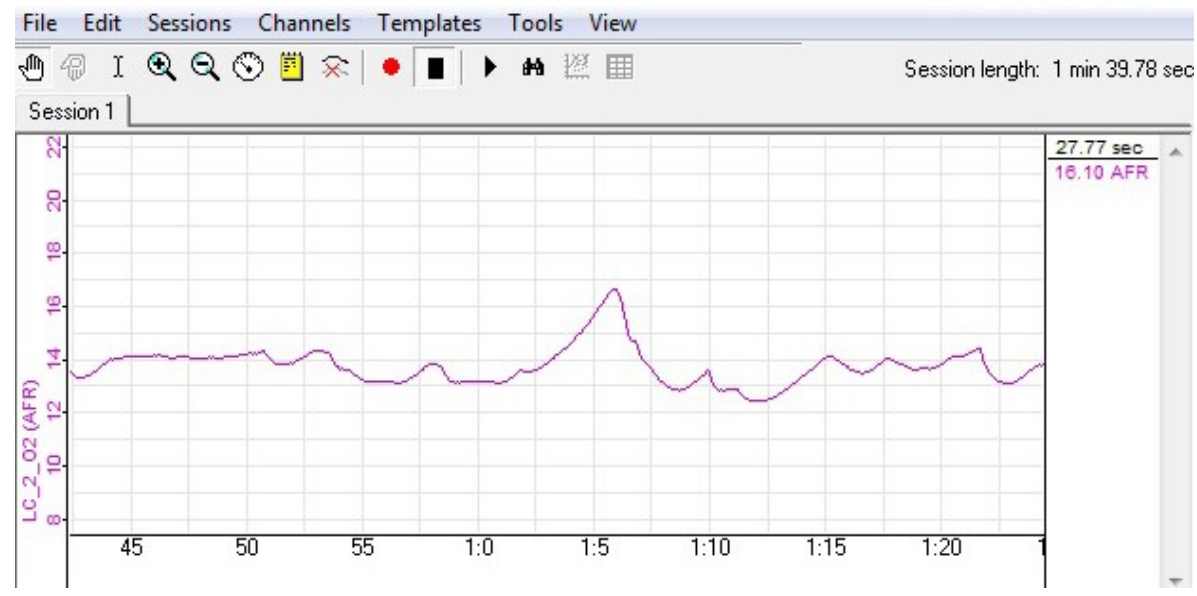

Fig. 15. Real-Time Log Environment

The program controls the air-fuel volume ratio depending on the duration of the analysis of the composition of the exhaust gases. The resulting graph can be obtained during the entire monitoring time and saved to a file with the $\log$ extension for further analysis and information processing.

This software has a direct connection with the developed digital $\alpha$-indicator, which allows controlling the PNC using a frequency controller, that is, to realize the possibility of correcting the operating modes of the fuel system by introducing feedback based on oxygen sensor signals. Fig. 3.23 shows the interaction of the $\alpha$-indicator with the software for different values of the air-fuel ratio.

The specified control system provides:

- rational using of the natural gas (savings of 5-10\% per year);

- reduction of electric power consumption by asynchronous wire motors of traction mechanisms (savings of 30-75\% per year);

- reduction of harmful substances in the atmosphere due to the complete combustion of fuel.

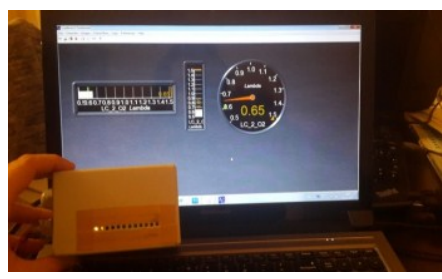

(a)

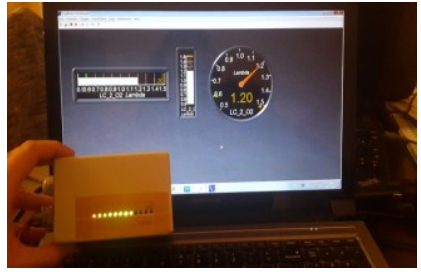

(b)

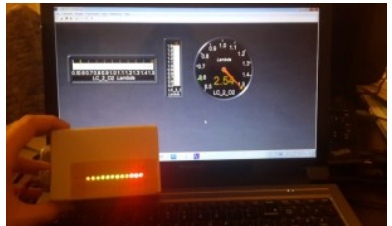

(c)

Fig. 16. The interaction of the $\alpha$-indicator and the developed software product in various modes of operation of the fuel system: $(a)$ enriched mixture; $(b)$ a mixture close to stoichiometric; $(c)$ lean mixture 
A system was developed and tested to determine and control the amount of heat of evaporation and the heat capacity of wet inhomogeneous materials, the use of which allows to experimentally obtain correct data to optimize the process of drying raw materials and, consequently, reduce costs and improve the quality of the final drying facility.

The proposed method and means of quasidifferential bomb calorimetry, which reduces the impact of external interference by 3...7 times compared to single-cell bomb calorimetry, or allows reducing the weight and size characteristics by $1.5 \ldots 2$ times compared to the classical differential bomb calorimetry.

Experimental studies of environmental and thermal parameters of the created system of monitoring and control of the process of fuel combustion in fuel systems with a stepwise correction of the ratio of the air-fuel mixture components were carried out. The use of such a system allows you to increase the efficiency of the fuel systems by $6 . . .20 \%$ compared with manual adjustment, reduce fuel consumption by $10 \ldots .25 \%$, maintain the concentration of $\mathrm{CO}$ and $\mathrm{NO}_{\mathrm{x}}$ in the exhaust gases at the level of European Union standards.

The combined use of the presented methods and means of improving production efficiency, quality control and fuel combustion from plant biomass makes it possible to increase the share of high-quality biofuels for the domestic market and for Ukraine to enter the international market for biofuel energy resources as one of the exporters of plant fuel cells.

\section{PЕФЕРАТ}

Артур Запорожещь, Сергій Іванов, Роман Сергієнко

Iнститут технічної теплофізики НАНУ, a.o.zaporozhets@nas.gov.ua

\section{ЗАСОБИ КОНТРОЛЮ ЯКОСТІ БІОПАЛИВ, ЇХ ВИРОБНИЦТВА ТА СПАЛЮВАННЯ}

Представлено пристрій для вимірювання теплоємності і теплоти випаровування вологи та органічних рідин з неоднорідних матеріалів, який реалізує метод синхронного термічного аналізу. Розглядаються конструкція пристрою і методи, що використовуються під час дослідження зразків біопалива. Наведено методи калібрування калориметричних платформ 3 використанням еталонного перетворювача теплового потоку. Представлено методи і технічні засоби калориметричного аналізу теплоти згорання біопалива. Запропоновано квазідиференціальний бомбовий калориметр для вимірювання питомої теплоємності спалювання зразків палива, розглянуто його структуру, модель $\mathrm{i}$ технічні характеристики. Запропоновано систему контролю якості процесу горіння в паливних системах, яка базується на зміні швидкості обертання дуттєвого вентилятора за сигналами сенсора кисню.

Ключові слова: біопалива, теплота випаровування, теплоємність, бомбовий калориметр, згоряння, контроль.

\section{PЕФЕРАТ}

Артур Запорожеи, Сергей Иванов, Роман Сергиенко

Институт технической теплофизики НАНУ, а.o.zaporozhets@nas.gov.ua

\section{СРЕДСТВА КОНТРОЛЯ КАЧЕСТВА БИОТОПЛИВ, ИХ ПРОИЗВОДСТВА И СЖИГАНИЯ}

Представлено устройство для измерения теплоемкости и теплоты испарения влаги и органических жидкостей из неоднородных материалов, которое реализует метод синхронного термического анализа. Рассматриваются конструкция устройства и методы, используемые при исследовании образцов биотоплива. Приведены методы калибровки калориметрических платформ с использованием эталонного преобразователя теплового потока. Представлены методы и технические средства для калориметрического анализа теплоты сгорания биотоплива. Предложен квазидифференциальный бомбовый калориметр для измерения удельной теплоемкости сжигания образцов топлива, рассмотрены его структура, модель и технические характеристики. Предложена система контроля качества процесса горения в топливных системах, которая базируется на изменении скорости вращения дутьевого вентилятора по сигналам сенсора кислорода.

Ключевые слова: биотоплива, теплота испарения, теплоемкость, бомбовый калориметр, сгорания, контроль. 


\section{ABSTRACT \\ Artur Zaporozhets, Serhii Ivanov, Roman Serhiienko \\ Institute of Engineering Thermophysics of NASU,a.o.zaporozhets@nas.gov.ua \\ MEANS OF QUALITY CONTROL OF BIOFUELS, THEIR PRODUCTION AND COMBUSTION}

A device for measuring the heat capacity and heat of evaporation of moisture and organic liquids from inhomogeneous materials is presented, which implements the method of synchronous thermal analysis. The installation design and methods used in the study of biofuel samples are considered. The methods of calibration of calorimetric platforms using a reference transducer of heat flow are given. Methods and technical means for calorimetric analysis of the calorific value of biofuels are presented. A quasidifferential bomb calorimeter for measuring the specific heat of combustion of fuel samples is proposed, its structure, model, and technical characteristics are considered. A system for monitoring the quality of the combustion process in fuel systems, which is based on the change in the rotational speed of the blower fan according to the oxygen sensor signals, is proposed.

Key words: biofuels, heat of evaporation, heat capacity, bomb calorimeter, combustion, control.

\section{REFERENCES}

1. Chernyak O. Energy Perspective 2030 for Ukraine in the Context of the EU integration / O. Chernyak, G. Kharlamova, A. Stavytskyy // Emerging Issues in the Global Economy, ed. by Mărginean S., Ogrean C., Orăștean R. - 2018. - P. 113-129. DOI: 10.1007/978-3-319-71876-7_10.

2. Ivanov S.O. The system for determining the heat of evaporation and the heat capacity of moist materials: dis. Cand. Tech Sciences: 05.11.04 / Ivanov Sergey. - K., 2017. - 179 p.

3. Theoretical and applied bases of economic, ecological and technological functioning of energy objects / [V. O. Artemchuk, T. R. Bilan, I. V. Blinov et al.]; eds. A. O. Zaporozhets, T. R. Bilan. - Kyiv, $2017 .-312$ p. 4. Ivanov S.O. Non-identity compensation of heat exchange conditions of measuring cells of a differential calorimeter during the study of the heat of evaporation / S.O. Ivanov // Information systems, mechanics and management. - 2017 - №16. - P. 100-104. DOI: 10.20535 / 2219-3804162017100799.

5. Research of thermal characteristics of willow shoots by devict of synchronous thermal analysis / N.V. Dmytrenko, S.O. Ivanov, Yu.F. Snezhkin, L.V. Dekusha // Industrial Heat Engineering. - 2015. - Vol. 35. - №2. - P. 77-84. DOI: 10.31472/ihe.2.2015.09.

6. Serhiienko R. Methods of Quality Control of Energy Efficient Characteristics of Biofuels and its Combistion / R. Serhiienko, S. Ivanov, A. Zaporozhets // International Journal "NDT Days". - 2018. - Vol. 1. - №2. - P. 222-227.

7. Analysis of the approximation of the results of measurements of a bomb calorimeter heat flux in nonstationary mode / V.P. Babak, A.O. Zaporozhets, A.O. Nazarenko, A.O. Redko // ScienceRise. - 2017. - T. 37. - № 8. - P. 24-32. DOI: 10.15587 / 2313-8416.2017.108935.

8. Research of the Energy Characteristics of Municipal Solid Waste in Cherkassy / [O. Sigal, Q. Boulanger, L. Vorobiov et al.]. // Journal of Engineering Sciences. - 2018. - Vol. 5. - №1. - P. 16-22. DOI: 10.21272/jes.2018.5(1).h3.

9. Provision of Diagnostic Systems for Energy Facilities / [V.P. Babak, S.V. Babak, M.V. Myslovych et al.]; ed by. V.P. Babak. - Kyiv, PH "Akademperiodyka", 2018. - 134 p. DOI: 10.15407/akademperiodyka.353.134.

10. Zaporozhets A.O. Investigation of the stoichiometric mixture of "air-fuel" organic compounds. Part 2. Alcines, alkins / A.O. Zaporozhets // Knowledge-based technologies. - 2014. - No 4. - P. 393-399. DOI: 10.18372 / 2310-5461.22.6803. 